\title{
Assimilation in North-Western England from the Norman Conquest to the Early Thirteenth Century: The Kirkby, Pennington and Copeland Families
}

\section{Paul Latimer}

To cite this article: Paul Latimer (2010) Assimilation in North-Western England from the Norman Conquest to the Early Thirteenth Century: The Kirkby, Pennington and Copeland Families, Northern History, 47:1, 49-66, DOI: 10.1179/174587010X12597746068462

To link to this article: https://doi.org/10.1179/174587010X12597746068462

\section{曲 Published online: 19 Jul 2013.}

Submit your article to this journal $₫$

Џ Article views: 61

4 Citing articles: 2 View citing articles 준 


\title{
ASSIMILATION IN NORTH-WESTERN ENGLAND FROM THE NORMAN CONQUEST TO THE EARLY THIRTEENTH CENTURY: THE KIRKBY, PENNINGTON AND COPELAND FAMILIES
}

\author{
PAUL LATIMER
}

Bilkent University

RECENT DECADES have seen a renewed interest in very old questions about the fate of English, or Anglo-Scandinavian, native families after the Norman Conquest of England, about the survival of such families as landholders above the level of the peasantry, about the adaptations made by such families and the assimilation that took place between them and the Norman and other Continental immigrants. ${ }^{1}$ The discussion has also concerned the nature and the consequences of the identity that emerged from that assimilation, and the success or failure to assimilate others to that resulting, dominant identity in different parts of the British Isles. ${ }^{2}$ Understandably, work on the initial assimilation has tended to concentrate on southern and Midland England, where the sources are much fuller. At the same time, however, there has been acknowledgement that the basis of relations between the conquerors and the conquered was significantly different in parts of the north of England, where the number of Continental immigrants was relatively small and where native landholders remained in place to a much greater extent. ${ }^{3}$ There is then good reason to look separately at the adaptations made in the North by native families and at the nature

\footnotetext{
${ }^{1}$ A. Williams, The English and the Norman Conquest (Woodbridge, 1995); J. Gillingham, 'Henry of Huntingdon and the Twelfth-Century Revival of the English Nation', in Concepts of National Identity in the Middle Ages, ed. S. Forde, L. Johnson and A. Murray (Leeds, 1995), pp. 75-101; H.M. Thomas, The English and the Normans: Ethnic Hostility, Assimilation and Identity 1066-c.1220 (Oxford, 2003). See also the introduction to M.G.I. Ray, 'Alien Knights in a Hostile Land: the Experience of Curial Knights in Thirteenth-Century England and the Assimilation of their Families', Historical Research, 79 (2006), 451-54.

2 J. Gillingham, 'The Beginnings of English Imperialism', Journal of Historical Sociology, 5:4 (1992), 392-409; J. Gillingham, 'The Foundations of a Disunited Kingdom', in Uniting the Kingdom? The Making of British History, ed. A. Grant and K. Stringer (1995), pp. 48-64; R.R. Davies, The First English Empire: Power and Identities in the British Isles, 1093-1343 (Oxford, 2000), pp. 117-20, 126, 170. The three articles by Gillingham cited above are conveniently republished in J. Gillingham, The English in the Twelfth Century (Woodbridge, 2000), pp. 3-18, 93-109, 123-44.

${ }^{3}$ Thomas, English and Normans, p. 112.
}

(C) The University of Leeds, 2010

DOI: $10.1179 / 174587010 X 12597746068462$ 
of their particular assimilation with Continental immigrants. The focus here will be on Furness and its surrounding areas, a part of the North that has received scant attention, looking at the Kirkby, Pennington and Copeland families, all of AngloScandinavian origin, all landholders in Furness as well as elsewhere in the NorthWest. While these families are certainly not the only ones that could be studied, there is a considerable amount of information about them in the sources and they can be seen as to some extent representative of the region's native landholders just below the level of tenant-in-chief. This article is concerned with how these Anglo-Scandinavian families adapted to the changed circumstances that arose after the Norman Conquest and will begin by looking at the situation towards the end of that process.

In November 1217, three neighbours in the Furness peninsula returned to Henry III's allegiance: Roger of Kirkby and Alan of Pennington, who held Kirkby Ireleth and Pennington respectively from the abbot of Furness; and Richard son of Alan, also known as Richard of Copeland, who held Great Urswick, Adgarley and Bolton from Michael of Furness, lord of Aldingham. ${ }^{4}$ There is no indication that the abbot of Furness or Michael of Furness were rebels in 1215-17, but Roger, Alan and Richard could also look for lordship to the rebel baron of Kendal, Gilbert Fitz Reinfrey.

The lords of Kendal, either William I of Lancaster (d. 1170) or perhaps his father Gilbert, had granted Dunnerdale, a substantial area of land in High Furness, to Roger of Kirkby's family. As the parish of Kirkby Ireleth stretched up as far as Seathwaite, well inside Dunnerdale, it is even possible that the claim of the lords of Kirkby Ireleth to the area preceded this grant. ${ }^{5}$ The Pennington family had held Tilberthwaite in High Furness from the barony of Kendal from the time of William I of Lancaster or William II of Lancaster (d. 1184). In addition, William I of Lancaster had claimed lordship over the Pennington holding in Muncaster, on the northern boundary of the lordship of Millom. ${ }^{6}$ The lords of Kendal were overlords of some of Richard son of Alan's holdings further north in Copeland. Hensingham near Whitehaven, for example, was held by Richard's father, Alan, from Roger son of Gilbert, who held it from his elder brother, William I of Lancaster, who in turn held it from the lordship of Copeland. ${ }^{7}$ Richard son of Alan had also been given land by Gilbert Fitz Reinfrey himself in the honour of Wallingford, at Shaw-cum-Donnington in Berkshire, and can be found witnessing one of Gilbert's charters. ${ }^{8}$

\footnotetext{
${ }^{4}$ Rotuli Litterarum Clausarum in Turri Londonensi Asservati, ed. T.D. Hardy, 2 vols, Record Commission (1835), I, 376; The Victoria History of the County of Lancaster, ed. W. Farrer and J. Brownbill, vIII (1914), 286, 300, 338-39, 387-89; W. Farrer, The Lancashire Pipe Rolls: also Early Lancashire Charters (Liverpool, 1902), p. 301; The Coucher Book of Furness Abbey, ed. J.C. Atkinson and J. Brownbill, 2 vols, 6 parts, Chetham Society, new series IX, XI, XIV, LXXIV, LXXVI, LXXVIII (1886-1919), I (1), 73, 128; I (2), 454-55; II (3), 778; Liber Feodorum: the Book of Fees commonly called Testa de Nevill, 3 vols (1920-31), I, 219; Rotuli Chartarum in Turri Londonensi asservati, ed. T.D. Hardy, Record Commission (1837), pp. 8-8b, 215b-216.

${ }^{5}$ Farrer, Early Lancashire Charters, pp. 442-43; VCH Lancs., vIII, 387-88.

${ }^{6}$ Furness Coucher Book, I (2), 351; Farrer, Early Lancashire Charters, pp. 304-05.

${ }^{7}$ The Register of the Priory of St Bees, ed. J. Wilson, Surtees Society, CXXVI (1915), 247-50, 259.

${ }^{8}$ VCH Berkshire, ed. W. Page and P.H. Ditchfield, IV (1924), 91, 209; W. Farrer, Records Relating to the Barony of Kendale, ed. J.F. Curwen, 3 vols (Kendal, 1923-26), I, 385-86. For subsequent holdings in Lonsdale of the Copeland family granted by William III of Lancaster, see Lancashire Inquests, Extents and Feudal Aids, 1205-1307, ed. W. Farrer, Record Society of Lancashire and Cheshire, XLVIII (1903), p. 256; Farrer, Barony of Kendale, II, 305, 308-09; VCH Lancs., VIII, 242-44.
} 
In the case of Roger of Kirkby and Richard son of Alan there is a clear indication that they were seen as the men of Gilbert Fitz Reinfrey. They were to provide hostages as part of the abortive surrender agreement made with King John in January 1216 to secure the release of Gilbert's captured son and knights. Richard son of Alan, here as Richard of Copeland, was to provide his daughter, while Roger of Kirkby was to provide his first-born son by Gilbert's daughter. There is reason to doubt that these hostages were ever handed over. ${ }^{9}$ Roger of Kirkby did, however, subsequently provide a son, Richard, as a hostage for the payment of William III of Lancaster's ransom. Richard was finally released in $1222 .{ }^{10} \mathrm{He}$ was not Roger of Kirkby's eldest son, who was the Alexander who succeeded Roger at least by January 1227 and who may have been the hostage specified in $1216 .{ }^{11}$ The hostage Richard seems to have been rewarded by a grant of land in Upper Rawcliffe to the west of Garstang and a small deathbed enfeoffment from William III of Lancaster in Whittle near Chorley. Richard also witnessed a grant to Furness Abbey made by William III's widow. ${ }^{12}$

Notice of the involvement of the Kirkby, Pennington and Copeland families in the rebellion and the inclusion of Roger of Kirkby and Richard of Copeland in Gilbert's hostage arrangements are signs of these families' status. We can also see them beginning to assume the expected role of knights in thirteenth-century English society, as electors, members and even leaders of assize and inquest juries, and as prominent witnesses in charters, where they were coming to be described as miles and dominus, more frequently the latter. ${ }^{13}$ The emergence into clearer visibility of men of knightly status who, while below the level of tenants-in-chief, came to form the backbone of English society and its administration in the thirteenth century and beyond is a familiar enough phenomenon. ${ }^{14}$ Yet there were of course other issues involved here. In terms of descent in the male line, Roger of Kirkby was the great-grandson of Orm son of Ailward; Alan of Pennington was the grandson of Gamel, while Richard son of Alan was the grandson of Ketel son of Ulf. In the early thirteenth century, Roger, Alan and Richard, with their unexceptional Continental forenames, appear as belonging to a relatively homogeneous, if at that time politically fractured, local and

\footnotetext{
${ }^{9}$ The verb dare used here in the Fine Rolls frequently means 'to promise to give': Rotuli de Oblatis et Finibus in Turri Londinensi asservati, ed. T.D. Hardy, Record Commission (1835), pp. 570-71; Rot. Chart., p. 221b. William III of Lancaster was still in custody in March 1217, while Gilbert's final peace with the Plantagenets was not until November 1217: Calendar of the Patent Rolls, Henry III, 1216-25, I, 45-46; Rot. Lit. Claus., I, 339b. Gilbert's daughter was presumably illegitimate; Roger's descendants did not share in the Lancaster inheritance after 1246: I.J. Sanders, English Baronies: a Study of their Origins and Descent, 1086-1327 (Oxford, 1960), p. 57.

${ }^{10}$ Rot. Lit. Claus., I, 497b.

${ }^{11}$ Final Concords of the County of Lancaster, ed. W. Farrer, RSLC, XXXIX (1899), 52-53. Only if Roger's marriage to Gilbert's daughter had been a second marriage could Richard have been the hostage specified in 1216.

${ }^{12}$ VCH Lancs., VII (1912), 268; Lancashire Inquests, p. 165; Furness Coucher Book, I (2), 367-68.

${ }^{13}$ Final Concords, pp. 34-35; Lancashire Inquests, pp. 257, 261; Register of St Bees, pp. 87-91, 99-100, 102-03; Furness Coucher Book, I (2) 450, 513-14, 519; II (3), 707, 745, 751-52, 758-59, 779, 785; Farrer, Barony of Kendale, I, 385-86, 391-92. In the charters cited above, the domini are usually distinct from and given priority over the $\underline{\text { milites }}$, while these knights follow the word militibus rather than precede it. On this, see D.F. Fleming, 'Milites as Attestors to Charters in England, 1101-1300', Albion, XXII (1990), 185-98. The evidence here, however, slightly conflicts with Fleming's more general description of this diplomatic practice.

${ }^{14}$ For a recent survey of the social groups concerned, see D. Carpenter, The Struggle for Mastery: 1066-1284 (2003), pp. 395-403.
} 
nationwide elite. A century earlier this would not have been the case. How did Roger of Kirkby, Alan of Pennington and Richard of Copeland come to be the kind of men they had become by the early thirteenth century?

It seems not to have been until after 1086 that the Norman Conquest began to have a direct impact on Furness and its adjoining areas, but in the course of William Rufus's and Henry I's reigns at the highest level of landholding this region received new lords, immigrants from Normandy and elsewhere on the Continent. ${ }^{15}$ Other immigrants arrived to receive land from these new tenants-in-chief. For example, the Boiville family were established as lords of Millom by William Meschin, lord of Copeland ${ }^{16}$ In 1127, Stephen of Blois, the holder of the honour of Lancaster, having three years earlier settled monks from Savigny at Tulketh near Preston, gave those monks half of Furness. Already by that time the Flemish Michael of Furness held the other half of Furness. ${ }^{17}$

However, while there were certainly further Continental immigrants, they seem to have been rather thinly spread. Hugh Thomas, writing of England as a whole, points out the importance for the process of assimilation of the integration of natives into neighbourhood aristocratic networks and of the presence of natives in the affinities of immigrant lords, interactions that became more common as time went on, but particularly after the middle of the twelfth century. He also notes, however, that in parts of the North, the conquerors both found it necessary, and were more willing, to accommodate existing elites. ${ }^{18}$ In Furness and adjoining areas, the neighbourhood aristocratic network seems to have remained, to a considerable extent, continuously a native one; native lords did not have to struggle their way back into such a network as they did in the south of England. Even though Continental settlement began in the North-West relatively late, this sort of interaction between natives and immigrants was more substantial earlier than in southern England.

A case in point is the Lancaster family, particularly significant here given the role played by Gilbert Fitz Reinfrey and his antecessors at Kendal in the histories of the Kirkby, Pennington and Copeland families. By the mid twelfth century, the Lancaster family held Kendal itself with its attached lands and lordship, dominating Kentdale, extending into Westmorland north of Shap as well as into Upper Ribblesdale and Lonsdale, and even across into Ewcross wapentake in Yorkshire. The family also held Ulverston in Furness and large tracts of the southern Cumbrian fells, and had acquired the fief of Warton and Garstang in the honour of Lancaster south of the sands. In addition, they retained lordship over lands in Copeland, including those that descended through Ketel son of Eldred to the later Curwen family of Workington. It

\footnotetext{
${ }^{15}$ G.W.S. Barrow, 'The Pattern of Lordship and Feudal Settlement in Cumbria', Journal of Medieval History, I (1975), 121-22; J.A. Green, The Aristocracy of Norman England (Cambridge, 1997), pp. 111-13, 119; R. Sharpe, Norman Rule in Cumbria 1092-1136 (Kendal, 2006), pp. 37-40.

${ }^{16}$ Either there were two Godard de Boivilles, father and son, or Godard de Boiville was the second holder preceded by an unnamed father: Register of St Bees, pp. 27-30; Furness Coucher Book, II (2), 522-23.

${ }^{17} \mathrm{He}$ also came to possess land in Lancashire south of the Sands at Thurnham: Farrer, Early Lancashire Charters, pp. 301-03; VCH Lancs., VIII, 286; Lancashire Inquests, p. 83.

${ }_{18}$ Thomas, English and Normans, pp. 112-18, 123-29.
} 
was from these rights in Copeland that the Lancaster family could claim overlordship of the Pennington holding at Muncaster, and of Richard of Copeland's holding at Hensingham near Whitehaven. ${ }^{19}$

Because of the sparse documentation in the period before 1150, it has been difficult to determine whether the Lancaster family was native or immigrant in the male line. Gilbert, the father of William I of Lancaster, has been regarded as a son or, more plausibly, brother of Ketel son of Eldred, a prominent native who had extensive holdings in both Copeland and Kentdale. ${ }^{20}$ However, it has also been claimed that Gilbert was a Norman who married Ketel's sister, on the grounds of Gilbert's apparently Continental name in the very early twelfth century, and because there is a reference to Ketel as William I of Lancaster's avunculus. ${ }^{21}$ Neither of these two latter arguments can bear much weight. Avunculus need not have the highly specific meaning of maternal uncle - both simply uncle or even grandfather are quite possible - while Gilbert was a common rendering in Latin sources of the Gaelic Gillebrigte, an unsurprising name to find in a family partly based in an area recently under Scottish control. ${ }^{22}$

While there can be no certainty here, it may well be that in the Lancaster family we have a native patrilineage at the heart of the aristocratic network of the region. The marriage in 1189 of William II of Lancaster's daughter and heiress, Helewise, to Gilbert Fitz Reinfrey might be seen as a dilution of the native element in the family, though whether it is sensible to talk in such terms by 1189 is a moot point. However, even Gilbert Fitz Reinfrey may not have been as purely Norman as he sounded. Roger Fitz Reinfrey, his father, had a brother with the name Edward. ${ }^{23}$

At their own less elevated level, members of the Kirkby, Pennington and Copeland families appear frequently in the documentation that is increasingly available from the mid twelfth century onwards, clearly forming part of the local aristocratic network. They appear as witnesses in the charters of the greater lords of the region, both immigrant and native - the lords of Copeland, Workington, Millom, Allerdale, Aldingham and Kendal — and in the charters of cadets of these lords' families. Those witnessing from the Kirkby family include Roger son of Orm, his son William and his grandson Roger of Kirkby. From the Pennington family there are Gamel of Pennington, his brother and son, Ketel and Benedict, as well as Benedict's wife Agnes and son Alan. From the Copeland family there are Ketel of Copeland, his son Alan

\footnotetext{
${ }^{19}$ The best account of the lands attached to Kendal is still Farrer, Barony of Kendale. See also Farrer, Early Lancashire Charters, pp. vii, 304-05, 310-14, 395-402; VCH Lancs., I (1906), 357-63; VCH Lancs., VIII, 349. For Muncaster and Hensingham, see above.

${ }^{20}$ Canon James Wilson's arguments in 1915 that Gilbert was Ketel's son rather than his brother are based on an ambiguous charter and a probable confusion between Orm son of Ketel son of Eldred and another Orm son of Ketel alive in 1094. In general, Gilbert and Ketel appear to be of the same generation: Register of St Bees, pp. 60-61, 248-49, 539-40; Farrer, Early Lancashire Charters, p. vii.

${ }^{21}$ G. Washington, 'The Parentage of William of Lancaster, Lord of Kendal', Transactions of the Cumberland and Westmorland Antiquarian and Archaeological Society, 2nd series, LXII (1962), 95-100.

${ }^{22}$ See, for instance, William of Newburgh's use of Gilbert for Gillebrigte son Fergus of Galloway: cited in R. Oram, The Lordship of Galloway (Edinburgh, 2000), p. 96.

${ }^{23}$ Reading Abbey Cartularies, ed. B.R. Kemp, 2 vols (1986-87), II, 314.
} 
and his grandson, Richard. ${ }^{24}$ Alan son of Ketel's appearance as witness in a charter of John Count of Mortain, lord of the honour of Lancaster, is exceptional in the high status of the grantor, ${ }^{25}$ but other appearances in documents reflect the families' status as local notables. Roger son of Orm is the only named individual in a prospective jury to decide a dispute between Michael of Furness and Furness Abbey. William son of this Roger and Benedict of Pennington appear as jurors in the settlement between Furness Abbey and William I of Lancaster over the division of the Furness fells. Alan son of Ketel is one of the pledges (for five marks) for Richard de Lucy's 300 mark fine to acquire the honour of Copeland in $1200 .{ }^{26}$ Members of the Kirkby, Pennington and Copeland families also appear in the charters of native families of status equivalent to or lower than their own, ${ }^{27}$ and in each other's documents. ${ }^{28}$

Thomas expresses reservations about the effectiveness of early aristocratic intermarriage as a means of assimilation in post-Conquest England as a whole, but these reservations have less force with reference to areas like Furness and Copeland. ${ }^{29}$ There, native marriage partners in mixed unions were members of an elite network of native landholding families that remained in place, marrying among themselves as well as with the newcomers. The earliest notice of the Kirkby family derives from the marriage, before 1118, of Orm son of Ailward to Emma, the daughter of Albert I de Grelley, first lord of Manchester and follower of Roger of Poitou. ${ }^{30}$ This is an interesting early example of a Norman lord giving his daughter to a native, which, as Thomas suggests, was not as uncommon as might be thought. ${ }^{31}$ As we have already seen, Orm's great-grandson, Roger of Kirkby, was to marry a daughter, albeit probably illegitimate, of Gilbert Fitz Reinfrey. The Flemish immigrant Michael of Furness probably married a native, as his daughter was given the English name Godith. She, in turn, was married to Ulf son of Eward, probably the ancestor of the Copeland family. ${ }^{32}$ Ulf's son, Efward of Copeland, often appearing with his brother

\footnotetext{
${ }^{24}$ Furness Coucher Book, I (2), 345-47, 418-19, 452, 514-15, 520-22; II (2), 569-71; II (3), 780, 782; Farrer, Barony of Kendale, II, 385-86; Register of St Bees, pp. 57-58, 60, 87-88, 196-97, 259, 382-83, 438-40, 461-62, 466 n. 4, 540-41, 544-46. The Ketel in the witness-list of a particularly early charter of Godard de Boiville may be Ketel of Copeland, as the charter in part concerns the church of Bootle, where the Copeland family had lands: ibid., pp. 106-07. Gamel of Pennington's appearance, along with his brother Ketel, as a witness of a charter by Alan son of Waltheof, lord of Allerdale seems to be his only occurrence as a charter witness: ibid., pp. 536-37.

${ }^{25}$ Furness Coucher Book, I (2), 418-19.

${ }^{26}$ Ibid., I (1), 74; Farrer, Early Lancashire Charters, pp. 310-14; Rot. Oblatis, p. 45.

${ }^{27}$ Furness Coucher Book, II (3), 704-05, 748-50; Register of St Bees, pp. 111-14, 116-17, 208-09, 310, 550-51, 559-60.

${ }^{28}$ Furness Coucher Book, I (2), 486, 510-11; II (3), 792; Farrer, Early Lancashire Charters, pp. 360-61.

${ }^{29}$ Thomas, English and Normans, pp. 146-55.

${ }^{30}$ Book of Fees, I, 214-15. For Albert I de Grelley and Roger of Poitou, see K. Thompson, 'Monasteries and Settlement in Norman Lancashire: Unpublished Charters of Roger the Poitevin', Transactions of the Historic Society of Lancashire and Cheshire, CXL (1990), 210-11, 213.

${ }^{31}$ Thomas, English and Normans, p. 130. For a discussion of the more studied phenomenon of English women marrying Norman men, see ibid., ch. 10.

${ }^{32}$ Book of Fees, I, 219. Farrer speculatively suggests that the grant in Adgarley, made with Michael's daughter Godith, was to Alan son of Ketel, but more probably Adgarley was part of the grant in 'maritagium' in Urswick to Ulf son of Eward recorded close by in the same source. The naming of one of the sons of the Copeland Ulf as Eward or Efward, Ketel being the other, makes it likely that the Ulf in Furness was indeed the Copeland Ulf and that his marriage was the source of the Copeland family's holdings in Furness: Lancashire Inquests, p. 83.
} 
Ketel of Copeland, was the ancestor of the family that took Waberthwaite as a toponymic. These Copeland brothers could thus claim Flemish descent through their mother. Efward seems to have gone on to develop a connection with the native Pennington family, Poulton le Sands passing from the Pennington family to Hugh son of Efward of Copeland by 1194 through yet another Godith, perhaps a daughter or granddaughter of Gamel of Pennington. ${ }^{33}$ Michael of Furness's daughter, Godith, made a second marriage to William of Easby (Great Easby, between Brampton and Lanercost in northern Cumberland). Despite his Continental name, William's descent is uncertain. His first wife, Hectreda or Etheldreda, seems certain to have been a native. Godith had by that time land in Copeland at Eaglesfield near Cockermouth, though the source of this land is not clear. ${ }^{34}$

Perhaps soon after the middle of the twelfth century, Robert de Boiville, the nephew of Godard de Boiville, married Margaret, daughter of Waltheof son of Edmund of Newby in Ewcross wapentake, Yorkshire. The wife of Godard de Boiville's grandson, Henry of Millom, was another Godith, while Henry of Millom's daughter, Aliz, married a William son of Waltheof. ${ }^{35}$ The maternal uncle of Gilbert Fitz Reinfrey's steward, Henry de Redmain, who had some minor holdings in Furness near Pennington, was possibly the same William son of Waltheof. ${ }^{36}$ It is hardly surprising that Roger, the younger brother of William I of Lancaster, whether purely native or not, married Sigerid, the widow of Waltheof lord of Allerdale, or that their father Gilbert's wife was called Godith. ${ }^{37}$ This was an aristocratic society in which Anglo-Scandinavian blood ran strongly; the arrival of prominent immigrants had not changed that.

The immigrants did, however, have a far-reaching influence on the native elites. When the Continental immigrant lords first arrived, they found a native elite with a mixture of Scandinavian and English personal names, the Scandinavian element predominating, a clearly different name-pool from that of the immigrants. In the course of the twelfth century this situation changed; the native elites progressively adopted names for their children, particularly for their male children, that would seem unexceptional, and perhaps unexceptionable, to the immigrants. By 1200, AngloScandinavian male forenames had become relatively rare at the upper levels of native society except as patronymics. These too would in time necessarily become rare.

In this, the native elite in the North-West acted no differently from surviving native patrilineages in southern and Midland England. However, the context was different: outside the North the elite was far more thoroughly dominated by Continental

\footnotetext{
${ }^{33}$ Lancashire Inquests, p. 89.

${ }^{34}$ Register of St Bees, pp. 83-84, 381-82.

${ }^{35}$ Furness Coucher Book, II (2), 303-04, 309-10, 554-55; W.S. Sykes, 'The de Boyvils of Millom and Kirksanton', CW 2, XLI (1941), 24.

${ }^{36}$ Roger of Kirkby and Michael of Furness (the grandson of the earlier Michael of Furness) witness the charter that supplies this information: Furness Coucher Book, I (2), 509. For Henry's office, see Farrer, Barony of Kendale, I, 384, 397. The Redmain family seem to have been descended, in the male line, from an Adam de Avranches, and held Levens and Selside of the barony of Kendal, as well as Yealand Redmayne of the Warton fee: ibid., I, 239, 391; II, 113.

${ }^{37}$ Register of St Bees, p. 50; CW 2, 96.
} 
immigrants and the pressure to conform was strong. Thomas stresses that the number of surviving native aristocratic patrilineages was relatively small 'outside the North'. ${ }^{38}$ Arguably, in the North-West pressure to conform was less, or at least different in nature. Perhaps we should see instead a more positive desire amongst the native elite to modernise and Europeanise their naming practices. It would be difficult to deny the influence, even through positive attraction, of the names of the immigrants, who had after all been inserted at the highest rank of landholders and were representatives of the conquerors of the English kingdom, but there were wider changes underway that affected immigrants and natives alike.

On a European scale, albeit with regional variation, the names of certain biblical characters and saints, as well as figures of increasingly widespread legend and romance, were growing in popularity: names like Adam, John, Peter, Thomas, Matthew, David, Arthur and Alexander. ${ }^{39}$ To a degree this relative homogenisation of European names was transmitted to the North-West of England through the immigrants to the natives, but perhaps the natives also directly embraced this change. It is also relevant in the case of the name Alexander that the kingdom of the Scots had already had one king of that name (1107-24) and was to have another in the early thirteenth century, Alexander II (1214-49).

Orm son of Ailward's Anglo-Scandinavian name did not prevent him from marrying a well-born Norman woman. Indeed, it was presumably because of his position amongst the Anglo-Scandinavian local elite that he obtained his bride. Yet, Orm's eldest son would be given the impeccably Norman name of Roger, succeeding his father at the latest by $1152 .{ }^{40}$ Roger's heir was William, and his heir in turn the Roger who was a rebel in 1217. Alexander of Kirkby followed Roger son of William by 1227 at the latest. ${ }^{41}$ What was probably a cadet branch of the family, with land in the lordship of Millom and at Angerton Moss in Furness just north of Kirkby Ireleth, retained its native names somewhat longer. Dolfin of Kirkby, Dolfin of Kirkby Junior, Ulf of Kirkby and Ulf of Kirkby Junior occur in the 1160s, alongside William son of Roger of Kirkby Ireleth. One of these Dolfins had a son, Orm, who witnessed charters around the beginning of the thirteenth century. However, he was succeeded by Alan, who made an agreement concerning Angerton Moss around 1235 and witnessed a charter in 1251 . He in turn was succeeded by a Ralph and then an Adam. $^{42}$

When Gamel of Pennington came to name his sons, his choices were somewhat more eccentric. Gamel's eldest son was named Benedict, a Latinate, explicitly Christian name not particularly common among laymen of any ethnicity. ${ }^{43}$ Gamel's

\footnotetext{
${ }^{38}$ Ironically though, the problem of 'hidden' native patrilineages in the south and Midlands seems more acute than in the North: Thomas, English and Normans, pp. 97-100, 130-31.

${ }^{39}$ R. Bartlett, The Making of Europe: Conquest, Colonization and Cultural Change, 950-1350 (1993), pp. $270-80$.

${ }^{40}$ Furness Coucher Book, II (2), 522-23.

${ }^{41}$ Final Concords, pp. 50, 52-53; Lancashire Inquests, p. 129. See also Furness Coucher Book, I (2), 318-19.

${ }^{42}$ Farrer, Early Lancashire Charters, p. 311; VCH Lancs., VIII, 398 n. 81, 402; Furness Coucher Book, I (2), 320-26; II (3), 746-49.

${ }^{43}$ Ketel of Copeland had a nepos, Benedict, though this could have been Benedict of Pennington himself. Ketel also had a son Benedict, though this too is possibly a result of close relations between the Copeland and Pennington families: Register of St Bees, pp. 57-58, 248, 385-86, 465-67, 541, 544- 46.
} 
second son was given the name Meldred, a rather uncommon name of obscure though possibly British origin that occurs in the form Maldred both in Strathclyde and Northumbria, notably in the Scottish royal family and the family of Earl Gospatric of Northumbria and later Dunbar. ${ }^{44}$ Swift, Waltheof and Rannulf of Pennington also occur as contemporaries of Benedict, and before 1185 a Jocelyn of Pennington was Abbot of Furness. In all these cases a family relationship is not clear, but cannot be ruled out. ${ }^{45}$ Benedict's son, Alan, the rebel of 1217, was old enough to witness charters alongside his father before 1184, though Benedict was still alive in $1186-87 .{ }^{46}$ Benedict had another son, Alexander. ${ }^{47}$ The wife of Benedict was named Agnes, which is a Continental name, but by the second half of the twelfth century cannot necessarily indicate Continental descent. Around 1200, Hugh son of Efward of Copeland, the nephew of Ketel of Copeland, had a daughter, Agnes. ${ }^{48}$ The heir of Alan son of Benedict was a second Alan by the 1240s, while other sons of Alan I were Adam and David. ${ }^{49}$ David should perhaps be seen as just one of the important biblical names that were becoming more widespread at the end of the twelfth century, rather than as a specifically British saint, though the presence of Meldred, Alan and David in the one family might not be mere coincidence. Although part of the immigrant namepool, Alan was associated particularly with the Breton contingent of the immigrants. Even though Bretons do not seem prominent in the North-West, Alan was a very popular choice there in the late twelfth and early thirteenth centuries. It is interesting that the Pennington family, except possibly in the cases of Rannulf and Jocelyn, seems to have avoided specifically Norman names.

Ulf of Copeland, marrying the English-named daughter, Godith, of the Flemish Michael of Furness, gave his two sons the Scandinavian and English names of Ketel and Efward respectively. Ulf was apparently dead before 1152, when both Ketel and Efward witness a charter of Godard de Boiville.$^{50}$ Ketel may still have been living in $1185 .^{51}$ Thereafter, the normal pattern asserts itself in this family too. Ketel's eldest

\footnotetext{
${ }^{44}$ Ibid., p. 116; Oram, Lordship of Galloway, pp. 32, 194. For a king of Dunmeller (now Drummelzier) in Upper Tweeddale near Peebles, associated with both St Kentigern and with Merlin, who supposedly met his death at the hands of the shepherds of a King Meldred, see C.W. Bruce, The Arthurian Name Dictionary (1999), p. 352. The Arthurian element here is perhaps not too far-fetched given Godard de Boiville's choice of Arthur for his son's name: Register of St Bees, p. 87. For another Meldred, in Yorkshire around the same time, see Furness Coucher Book, II (1), 314.

${ }^{45}$ Farrer, Early Lancashire Charters, p. 311; Register of St Bees, pp. 110-11; Furness Coucher Book, I (3), xxxvi-xxxviii; II (2), 522-23.

${ }^{46}$ Register of St Bees, p. 259; Pipe Roll 33 Henry II, p. 18. For other examples of Alan appearing in charters alongside his father, see Register of St Bees, pp. 64-67, 111-12; Farrer, Early Lancashire Charters, pp. 360-61.

${ }^{47}$ Register of St Bees, p. $111 \mathrm{n}$. 1. The editor here suggests that Alexander was probably a mistake for Alan, but Alexander son of Benedict of Pennington also appears in a charter of William son of Michael of Furness to Furness Abbey and in the Pipe Rolls: Furness Coucher Book, II (3), 782; Pipe Roll 31 Henry II, p. 187.

${ }^{48}$ Furness Coucher Book, II (2), 303-04; Farrer, Early Lancashire Charters, pp. 360-61; Register of St Bees, pp. 464-66.

${ }^{49}$ Furness Coucher Book, II (2), 563-64; Register of St Bees, p. 58. David was known as David of Mulcaster (i.e. Muncaster). One of the charters that mentions him is dated by the editor as around 1210, which would make David the brother of Alan son of Benedict, but there seems no reason for such an early dating and the other charters suggest he is Alan I's son: Furness Coucher Book, II (2), 561-65.

${ }^{50}$ Furness Coucher Book, II (2), 522-23.

${ }^{51}$ Register of St Bees, p. 115. This document also mentions Alan miles, immediately after Ketel, which may refer to Ketel's eldest son.
} 
son Alan was, as we have seen, succeeded in the early thirteenth century by his son Richard. ${ }^{52}$ Alan also had at least three brothers: William, Michael and Benedict, and possibly another, Adam. The adoption of Michael as a name presumably derives at least partly from the family's marital and tenurial connections with the lords of Aldingham..$^{53}$ As we have seen, the Waberthwaite branch of the family at least had connections with the Pennington family. It may have been for this reason that the name Benedict was chosen. Ketel of Copeland's brother, Efward, called his eldest son Hugh, who seems roughly contemporary with his first cousin, Alan son of Ketel. ${ }^{54}$ Hugh's son and successor by 1208 was William. ${ }^{55}$ Hugh's daughter, Agnes, has already been mentioned. These families thus illustrate a clear process of Europeanisation in their naming practices, though they also show how specifically local, even personal, factors might shape that process.

Forms of land tenure in the North-West changed in the course of the twelfth century after the Norman penetration of the area. Although older tenures survived, often commuted to cash payments, sometimes together with some restricted military service, the notion of tenure by knight service, along with that of the fee-farm, gained ground. ${ }^{56}$ The mixture that resulted is witnessed on the lands held by the Kirkby, Pennington and Copeland families. The holdings gained by Orm son of Ailward from his marriage to Emma de Grelley, Wrightington, Parbold and Dalton in southern Lancashire, were described as one knight's fee, at least by 1212 . Other Kirkby holdings from the Grelley family, Ashton-under-Lyne, Osulf's Croft and Heaton, were held 'in fee and inheritance' but for fixed sums per annum, suggesting some kind of fee-farm. ${ }^{57}$ Likewise, the Kirkby land in Dunnerdale in High Furness was held 'in fee and inheritance' in return for $4 s$. annually at Christmas, though a fifteenth-century record adds that military service was owed on top of the cash render. ${ }^{58}$ On the other hand, by 1210-12, the Kirkby family had also acquired, presumably directly of the honour of Lancaster, one carucate in Reddish to the south-east of Manchester, in return for $6 s$. thanage or drengage..$^{59}$

The first concrete indication of the Kirkby family's presence at Kirkby Ireleth is Roger son of Orm's witnessing, as Roger of Kirkby, of Godard de Boiville's charter to Furness Abbey, issued by 1152, although the family's tenure may go back much

\footnotetext{
52 Ibid., pp. $544-46$.

${ }^{53}$ Ibid., pp. 60, 251, 464-66, 544-46.

54 They both witness Benedict of Pennington's grant to Rushen with their fathers: Furness Coucher Book, II (3), $792-93$

${ }^{55}$ Register of St Bees, pp. 289-91, 464-66; Furness Coucher Book, I (2), 10-11; II (3), 792-93.

${ }^{56}$ Interestingly, the knight service in the king's army due from Copeland was limited to Wales and Scotland, resembling the limitation of military service from many cornage tenures to service against the Scots: Book of Fees, I, 197-99. This limitation on military service from cornage tenures became of subject of dispute in King John's reign: J.C. Holt, The Northerners: a Study in the Reign of King John (Oxford, 1961), pp. 91-92.

${ }^{57}$ These lands were subsequently granted to others, though the Kirkbys' claim to lordship was maintained: Book of Fees, I, 214-15; Farrer, Early Lancashire Charters, pp. 403-06.

${ }^{58}$ Farrer, Early Lancashire Charters, pp. 442-43; Furness Coucher Book, I (2), 351.

${ }^{59}$ A Matthew of Reddish appears to have been the tenant there. In 1226-28, it was said that Alexander of Kirkby 'ought to hold' this carcuate for $6 \mathrm{~s}$., perhaps indicating some difficulty in maintaining lordship over it: Lancashire Inquests, p. 69; Book of Fees, I, 216, 367; The Red Book of the Exchequer, ed. H. Hall, 3 vols, Rolls Series (1896), II, 573.
} 
earlier, perhaps even before the foundation of Furness Abbey. ${ }^{60}$ Whether the Kirkbys' tenure from Furness Abbey was by knight service or not, and specifically whether wardship and homage ought to be required, became a matter of dispute in the fourteenth century. At the same time the abbey claimed miscellaneous services going back to pre-Conquest forms of tenure. During these proceedings, the abbey claimed that Pennington's tenure was similar. ${ }^{61}$ However, while an inquest of Henry V's time found the manor of Pennington to be held by knight-service and the service of $30 \mathrm{~s}$. annually, in 1431 the Crown accepted that Kirkby Ireleth's tenure was not by knight-service, but by socage. By that time, this term was perhaps being used simply to indicate land held in return for a fixed render, but not by knight-service or by fee-farm. ${ }^{62}$

The Pennington family's tenure at Tilberthwaite near Coniston, at least as described in the early fifteenth century, included military service and $1 \frac{1}{2} d$. per annum, while the family's tenure in Westmorland, perhaps at Orton, was in 1201 still cornage. ${ }^{63}$ Some at least of the Copeland family's holdings in Copeland itself were traditional tenures. ${ }^{64}$ The family's tenures from Michael of Furness seem in most cases to have consisted of a fixed payment in accordance with the proportion held of Michael's own 201/2 carucates. Whether this indicates a fee-farm as Michael's own holding in Furness seems to have been, giving the lord homage and rights of wardship, is not and, one suspects, was not clear. ${ }^{65}$ Some additional parcels of land were granted by William son of Michael of Furness to Alan son of Ketel 'for homage and service', the service to consist of a render of $32 d$. 'with other forensic service', suggesting a military tenure in principle at least. ${ }^{66}$ It may well be that, with or without the rather minimal actual knight-service typical of the North-West, precise distinctions between different kinds of tenures that provided a fixed cash render only became truly significant by the fourteenth and fifteenth centuries, leading to disputes like that involving Kirkby Ireleth.

Tenures then varied, and so did the lordships from which they were held. The Kirkby family's holdings may have been all within the honour of Lancaster, but the immediate lords included Furness Abbey, the Lancaster family, the Grelley family, as well as the honour of Lancaster itself, while a probable cadet line of the family held land from Furness Abbey, the lords of Millom and the local Broughton family. ${ }^{67}$

The Pennington lands, fairly widely scattered, were held of a number of lordships. Pennington in Furness was held from Furness Abbey, while Muncaster was part of the lordship of Copeland, with the Lancaster family claiming to hold an intermediate

\footnotetext{
${ }^{60}$ Furness Coucher Book, II (2), 522-23. William Farrer mistakenly identified 'Roger Bristold' in Furness's foundation grant as Roger of Kirkby, a William 'Brictwald' later appearing as a juror alongside Roger of Kirkby's son, William: Farrer, Early Lancashire Charters, pp. 303, 311. See also Furness Coucher Book, II (2), 748n., 753-54.

${ }^{61}$ Furness Coucher Book, I (2), 310-16.

${ }^{62}$ Ibid., I (1), 131-38; I (2), 484-85; Inquisitions and Assessments relating to Feudal Aids, 1284-1431, III (1904), 93.

${ }^{63}$ Furness Coucher Book, I (2), 351; Rot. Oblatis, p. 161.

${ }^{64} \mathrm{See}$, for example, the drengage tenure in High Bolton in Copeland: Register of St Bees, pp. $247-52$.

${ }^{65}$ Book of Fees, I, 219; Pipe Roll 16 Henry II, p. 53; VCH Lancs., VIII, 286, 300. See also Book of Fees, I, 219, where the word feodum is used, though only in respect of Michael of Furness's land in Lancashire south of the sands.

${ }^{66}$ Furness Coucher Book, I (1), 73.

${ }^{67}$ Ibid., I (2), 320-26.
} 
lordship. In 1208, the claims of Alan of Pennington at Ravenglass were settled by Richard de Lucy, lord of Copeland, by means of grants at Sosgill and Mockerkin south of Cockermouth. Lands south of the River Esk, between Muncaster and Bootle and at Corney and Whitbeck, were under the lordship of Millom. Orton in Westmorland answered to that shire, while Poulton le Sands was part of the honour of Lancaster. ${ }^{68}$ At Tilberthwaite in High Furness, the Penningtons held, as we have seen, from the Lancaster family. At some point, possibly in the twelfth century, or in the thirteenth century when a cadet branch of the Penningtons had possession of Muncaster, land was acquired at Giffen in Ayrshire, presumably under Cunningham's Morville lords. ${ }^{69}$

The Copeland family also answered to a number of lords: the lords of Aldingham; the Lancaster family including its cadet line; the lords of Millom, and the lords of Copeland themselves. ${ }^{70}$ If the north-west of England, like the south-west of Scotland and Wales, was characterised by large, compact lordships that may have reflected much older divisions of the land, ${ }^{71}$ beneath the top level of lordship landholding often cut across these neat divisions. With multiple lords, individual instances of lordship in themselves were unlikely to determine completely the allegiances and behaviour of families. In this respect, their situation was perhaps less dissimilar from the knights of southern and Midland England than a superficial contrast between tenurial simplicity in the North and tenurial complexity in the south would suggest. ${ }^{72}$

Continental immigrants to the North-West came from lands with castles, boroughs and markets. It was natural that they try to reproduce these military and economic institutions in their new home, but it is also not surprising that the castles came first. What seem to be early wooden and earthwork castles have been found in the Kendal lordship at 'Bodelforde', Kirkby Lonsdale and Kendal, where later there was also a stone castle. Godard de Boiville or his father presumably built the first castle at Millom and in Furness the first Michael of Furness was the likely builder of the early

${ }^{68}$ The churches of Muncaster, Whitbeck, Pennington, Sker-overton (Orton) and Poulton had been granted to Conishead Priory by Gamel of Pennington: Farrer, Early Lancashire Charters, p. 357. For Soskill and Mockerkin, see Register of St Bees, p. 140 n. 3. For Corney and the other land south of the Esk in Copeland, see ibid., pp. 112-13; Furness Coucher Book, I (2), 510-11; II (2), 563-64. It is possible that Gamel had land further north, too, given the claims of the hospital of Conishead at Weddicar near Whitehaven, though these claims might also derive from the Lancaster family: Register of St Bees, p. 119. After passing from the Pennington family to the Waberthwaite family, Poulton passed, by 1212, to Walter de Parles: Lancashire Inquests, p. 89. For the continuation of Pennington holdings in Westmorland, see J. Nicholson and R. Burn, The History and Antiquities of the Counties of Westmorland and Cumberland, 2 vols (1777), I, 482, 485; Rot. Lit. Claus., I, 376; Rot. Oblatis, p. 161.

${ }^{69}$ G.W.S. Barrow, The Anglo-Norman Era in Scottish History (Oxford, 1980), pp. 186-87; Barrow, Journal of Medieval History, I (1975), 131.

${ }^{70}$ The pledge towards Richard de Lucy's fine for the honour of Copeland is suggestive of the family's status in Copeland: Rot. Oblatis, p. 45. In Copeland north of the Esk, apart from Hensingham and High Bolton, already mentioned, the family held land in Santon in Irton and at Haile south of Egremont (Alan son of Ketel's brother, Adam): Register of St Bees, pp. 252-53, 310. For holdings from the lords of Millom, see ibid, pp. 279-80; Furness Coucher Book, II (2), 523-24. For land held by Benedict the brother of Alan son of Ketel, see Register of St Bees, p. 541.

${ }^{71}$ Barrow, Journal of Medieval History, I, 122-25, 132-35.

${ }^{72}$ For a study of knights' allegiances further south, see Kathryn Faulkner, 'The Knights in the Magna Carta Civil War', in Thirteenth-Century England VII, ed. M. Prestwich, R. Britnell and R. Frame (Woodbridge, 2001), pp. 1-11. 
castle at Aldingham. Especially notable, though, is that there was also an early castle at Pennington, so perhaps the native family of Pennington was also quick to adopt the practice. ${ }^{73}$

If, in the second half of the eleventh century, southern and Midland England, like Normandy and Flanders, had a relatively urbanised and commercialised economy, Furness and its adjoining areas did not. In contrast to the fairly quick introduction of castles there, the spread of a more sophisticated economy was markedly slow and late, only really beginning to make progress at the end of the twelfth century. Perhaps around 1200 and certainly by 1220, Gilbert Fitz Reinfrey founded a borough at Ulverston in Furness, having earlier, in 1189, established a Saturday market at Kendal. It was only under William III of Lancaster that Kendal itself became a borough. Also in the very early thirteenth century, Furness Abbey was developing a market at Dalton-in-Furness and had added a fair there by $1245-46 .{ }^{74}$ Tardy and limited though these steps were, they began to make the area look less economically primitive.

In the second half of the twelfth century, the Kirkby, Pennington and Copeland families, like others in the area, both native and immigrant, began to have more regular contact with royal administration and had to cope with the activities of sheriffs and royal justices. Following an eyre by Ranulf de Glanville, Roger son of William of Kirkby Ireleth had to answer in $1180-81$ for $£ 1$ because he had seized unjustly the cattle of Henry the Clerk. ${ }^{75}$ In 1200, the same Roger faced the heavy fine of fifty marks and two hunting horses as a pledge to answer the accusation that he had killed Matthew son of Simon of Broughton in Furness. ${ }^{76}$ Benedict of Pennington twice fell foul of royal justices in the last decade of Henry II's reign, on the first occasion having to pay three marks, and on the second, $£ 5 .{ }^{77}$ In 1201, Alan son of Benedict had to fine for $£ 5$ not to have to cross the Channel to Normandy to do military service for a cornage tenure of one carucate in Westmorland. ${ }^{78}$ Another eyre in 1209-10 led to Alan paying a small amercement. ${ }^{79}$ In 1208-09, Alan son of Ketel of Copeland fined in Cumberland for thirty marks and one palfrey for an inquiry into whether or not he had removed the serjeants who looked after the pleas of the Crown in Copeland. ${ }^{80}$ Alan's uncle, Efward, and possibly Alan's brothers Adam and Benedict, also occur making payments in the Pipe Rolls ${ }^{81}$ Such contacts with royal

\footnotetext{
${ }^{73}$ M.C. Higham, 'The Mottes of North Lancashire, Lonsdale and South Cumbria', $C W 2$, XCI (1991), 79-84, 88-89. See also D.R. Perriam and J. Robinson, The Medieval Fortified Buildings of Cumbria, CWAAS, extra series, XXIX (1998), 375, 388.

${ }^{74}$ J. Munby, 'Medieval Kendal: the First Borough Charter and its Connections', CW 2, LXxxv (1985), 97-98; Furness Coucher Book, I (1), 131, 149.

${ }^{75}$ Pipe Roll 27 Henry II, p. 25; Pipe Roll 28 Henry II, p. 137.

${ }^{76}$ Rot. Oblatis, p. 98; Pipe Roll 3 John, p. 273. The cadet family of Kirkby Ireleth held land from the Broughton family: Furness Coucher Book, I (2), 324-26.

${ }^{77}$ For failing to follow through a claim: Pipe Roll 31 Henry II, p. 186; for default: Pipe Roll 33 Henry II, p. 18; Pipe Roll 34 Henry II, p. 51.

${ }^{78}$ Rot. Oblatis, p. 161. In the Pipe Roll record of this, he is listed amongst the drengs who made such fines: Pipe Roll 3 John, p. 257.

${ }^{79}$ Pipe Roll 12 John, p. 37; Pipe Roll 13 John, p. 155.

${ }^{80}$ Pipe Roll 11 John, p. 94; Pipe Roll 12 John, p. 138.

${ }^{81}$ Pipe Roll 30 Henry II, p. 42; Pipe Roll 4 John, p. 157; Pipe Roll 12 John, p. 32; Pipe Roll 13 John, pp. 42, 154.
} 
administration, while not always comfortable, involved these families in what was the common experience of the landed elites throughout the kingdom.

Local families were also encountering the developing institutions of ecclesiastical government. By the late twelfth century, we see Roger, the parson appointed by the Kirkby family to the church of Kirkby Ireleth in the late twelfth century, cooperating with the archdeacon of Richmond, the archdeacon's official, the vice-archdeacon and the rural deans of Copeland and Lancaster, as well as with the leaders of local monastic houses. It is possible Roger even became Dean of Lancaster himself. Roger had a brother, Alan, and, given the popularity of this name among native families, it is possible that Roger was a native, perhaps even a member of the Kirkby family. ${ }^{82}$

When Benedict of Pennington granted land on Skeldou Moor, south of Muncaster, to Rushen Abbey, Furness Abbey's daughter house on the Isle of Man, the grant was witnessed not only by the Prior of Furness Abbey, but by the Dean of Copeland, the parson of Millom and the priest of Ponsonby in Copeland north of the Esk. Among the laymen witnessing were Efward son of Ulf of Copeland and Ketel his brother, Hugh son of Efward and Alan son of Ketel..$^{83}$ The Penningtons' role in the foundation of Conishead Priory (see below) also brought them into contact with the archbishop of York, the archdeacon of Richmond, his deputy and his official, as well as the dean and chapter of Lancaster. ${ }^{84}$

Sometimes ecclesiastical and royal authorities overlapped. In 1184-85, Alexander, a younger son of Benedict of Pennington, offered the justices one mark for a licence to make an agreement with Christina the daughter of Copsi. The agreement was probably made in the presence of Godfrey de Lucy, who was both Archdeacon of Richmond and a royal justice on eyre in Cumberland in 1185. Godfrey also received the results of an inquisition made by the chapter of the deanery of Copeland about Copsi's church of Corney in the lordship of Millom. This inquisition was made up of both clerks and laymen, the latter including Ketel son of Ulf of Copeland, together probably with his son, described here as Alanus miles, Meldred son of Gamel of Pennington and Benedict, either a son of Meldred or possibly Benedict son of Gamel himself. Copsi's daughter Christina had married a certain Waltheof, who may well have been the otherwise obscure Waltheof of Pennington. Copsi granted the church to St Bees and this was confirmed by his son and grandson, but also by Benedict of Pennington. ${ }^{85}$

The chapter of the deanery of Copeland witnessed Alan son of Ketel's grant from Hensingham near Whitehaven to St Bees ${ }^{86}$ In turn, Alan, alongside the deputy Archdeacon of Richmond, the Dean of Copeland and other local priests, was one of the laymen who witnessed Robert of Harrington's grant to St Bees of the church of Harrington near Workington. Likewise, he witnessed a recognition by T. clerk of

\footnotetext{
${ }^{82}$ Register of St Bees, p. 136, 204 and perhaps also pp. 109-10; Farrer, Early Lancashire Charters, pp. 360-67; Furness Coucher Book, I (2), 451-53; II (3), 711-12, 749-51.

${ }^{83}$ Furness Coucher Book, I (2), 510-11; II (3), 792-93.

${ }^{84}$ Farrer, Early Lancashire Charters, pp. 357-58, 360-61, 366-67.

${ }^{85}$ Pipe Roll 31 Henry II, p. 187; Register of St Bees, pp. 111-16.

${ }^{86}$ Register of St Bees, pp. $250-51$.
} 
Dean (also near Workington) made before the official of the Archdeacon of Richmond and the Dean of Copeland. Roger the parson of Kirkby Ireleth also witnessed the latter document. ${ }^{87}$

The local secular Church was developing, not only organisationally but physically. The earliest stonework on extant churches in the Furness peninsula dates back to the twelfth century, at Kirkby Ireleth, Urswick and Aldingham. Aldingham Church was presumably built in stone by Michael of Furness or one of his early descendants. Michael made one of his sons, Daniel, rector of the church. The advowson of Urswick Church was also held by the lords of Aldingham, so perhaps they built that too..$^{88}$

The oldest surviving part of the church of Kirkby Ireleth is its twelfth-century 'Norman' doorway. The Kirkby family presumably constructed this church. ${ }^{89}$ The family's proprietary interest in the church was not extinguished easily. The advowson was first surrendered to Furness Abbey by William son of Roger, with a proviso that Roger, the Kirkby family's incumbent parson, was allowed a life tenure. There was a further quitclaim in 1227 by William's grandson, Alexander. In 1228, however, Kirkby Church was retained by Walter de Gray, Archbishop of York and, in 1230, it was given to York Minster, part of a wider compromise between Furness Abbey and the secular Church whereby Urswick and Dalton churches and half of Millom Church were conceded to the abbey, whereas Kirkby Ireleth Church and the other half of Millom were retained by the Archbishop. ${ }^{90}$ The role of archdeacons and local deans, the appetite of the Church, both secular and regular, for advowsons, and the Church's struggle against what had amounted to proprietary churches, all indicate how the local Church was being propelled towards the ecclesiastical mainstream of England and Europe, with local families involved, one way or another, in the process.

At some time around the middle of the twelfth century, an inscription in Old Norse was carved on a church tympanum found later on a farm in Pennington: 'kamial seti besa kirk Hubert masun uan' (Gamel founded the church and Hubert the mason constructed it). The author of the inscription was most likely Gamel of Pennington. ${ }^{91}$ Evidently Old Norse was of sufficient importance to Gamel for him to place it on his church, but, if this reflected his past, the building of a stone church was part of the new developments. Gamel was taking an active role by employing an apparently Continental mason to build his Continental, stone church.

While local native families were actively involved in the transformation of the local secular Church, the arrival of Continental, reformed monasticism in the form of the Furness Abbey in 1127 had a substantial impact without initially eliciting much positive involvement from those families. Probably landholders in Furness prior to Stephen Count of Mortain's foundation of the abbey, the Kirkby and Pennington

\footnotetext{
${ }^{87}$ Ibid., pp. 116-17, 136.

${ }^{88}$ Furness Coucher Book, I (2), 452; II (2), 520-21; Farrer, Early Lancashire Charters, pp. 360-61, 366-67; VCH Lancs., VIII, 328-31.

${ }^{89}$ VCH Lancs., VIII, 387-88.

${ }^{90}$ Ibid., 389; Furness Coucher Book, I (2), 318-19; I (3), 652-53; II (2), 555-57.

${ }^{91}$ E.V. Gordon, An Introduction to Old Norse, 2nd edn, rev. A.R. Taylor (Oxford, 1957), p. 186; A.J.L. Winchester, Landscape and Society in Medieval Cumbria (Edinburgh, 1987), p. 24; F. Barnes, Barrow and District (Barrow-in-Furness, 1968), pp. 16-17.
} 
families and others found themselves suddenly with a new lord interposed between themselves and Stephen. There is no indication that they were consulted, or that they assisted the foundation and initial endowment. ${ }^{92}$ Even by 1152 Furness Abbey does not seem to have attracted donations from native locals. ${ }^{93}$ Subsequently, one of the earliest grants to Furness Abbey by a native, Waltheof son of Edmund's grant of Newby in Ewcross wapentake, was probably prompted by his daughter's marriage to Robert de Boiville, the nephew of the lord of Millom. ${ }^{94}$

The abbey's local relationships, perhaps because of its extensive endowment and ambitious claims, seem to have been initially rather prickly. Exchanges made with Michael of Furness were not without their disputed points and generated many documents. ${ }^{95}$ Relations with the Lancaster family proved stormy because of the abbey's claims over the Furness fells and Ulverston, and the Lancaster family's involvement in the foundation of Conishead Priory. William I of Lancaster's grant to the abbey of lordship over the Pennington vill of Muncaster may have been the earliest of all native grants, but Furness Abbey could not maintain the claim; Gamel of Pennington granted Muncaster Church to Conishead Priory instead. ${ }^{96}$ Also, while Benedict of Pennington and his brother Meldred made, as we have seen, a grant of land near Bootle to Furness Abbey's daughter house on the Isle of Man, they gave no grant to Furness Abbey itself. Benedict's son Alan had dealings with the abbey, but they seem to have consisted more of dispute settlement than of patronage. ${ }^{97}$ Nevertheless, there are signs that the abbey gradually began to integrate itself into the local community. In the second half of the twelfth century, the abbots seem increasingly to have been local men, one of whom - Jocelyn of Pennington - may even have been a member of the Pennington family. Jocelyn was, it seems, a man of the schools, an inceptor in theologia, and a man who obtained a papal privilege for the abbey. ${ }^{98}$ Local men, too, had changed.

For some time, Furness Abbey was the only monastic community in the area, or at least the only community recognisable as such to Continental immigrants, but by 1181 at the latest, there was a hospital just to the south of Ulverston, at Conishead, and this was converted by 1184 into a priory of Augustinian canons. Conishead itself appears to have been granted by William II of Lancaster, but Gamel of Pennington's several grants from his scattered properties could have been made as early, if not earlier, and Gamel may well have been at least a co-founder of the hospital. Furness Abbey, indeed, seems to have been concerned about Pennington Church and about the possibility of a rival monastery in Furness as early as 1154-59, and it is possible the hospital had an earlier history in some form. The head of the hospital's brothers

\footnotetext{
${ }^{92}$ Roger 'Bristold' or 'Brictwald' is explicitly included in the foundation grant together with his possessions, but there is no indication of his consent: Farrer, Early Lancashire Charters, pp. 301-03.

${ }_{93}^{93}$ Furness Coucher Book, I (3), 591-94.

${ }^{94}$ Ibid., II (1), 296-97, 303-04, 308-09, 309-10, 311-12. Another early, small Yorkshire donation near Giggleswick was made by Adam son of Meldred.: ibid., II (1), 314.

${ }^{95}$ Farrer, Early Lancashire Charters, pp. 307-09; Furness Coucher Book, I (1), 73-77; I (2), 451, 454-57.

${ }^{96}$ Farrer, Early Lancashire Charters, pp. 304-05, 310-14, 357; Furness Coucher Book, I (2), 345-47, 392-94, 418-20, 437-42.

${ }^{97}$ Furness Coucher Book, I (2), 485-86, 510-11.

${ }^{98}$ Ibid., I (1), 9; II (3), xxxvii-Xxxviii.
} 
was one Gillamichael, an Irish or Scots name, perhaps an unlikely appointment for a completely new, recent foundation, while the hospital possessed some tithes at Weddicar, east of Whitehaven. These tithes could conceivably have come from the Lancaster family, their relatives the Curwen family, or even from the Penningtons, though we do not know that they held land so far north. ${ }^{99}$ Another hospital was founded before 1184 at Ravenglass by Efward son of Ulf, the head of the Waberthwaite branch of the Copeland family. ${ }^{100}$

Apart from their involvement with Conishead, the Lancaster family had also earlier, around 1153-54, founded a house of Augustinian canons across Morecambe Bay at Cockerham, at first dependent on Leicester Abbey, but which had its own prior by 1208 . Nearby, by 1184 , the family was patronising a hospital at Cockersand, which became a Premonstratensian priory by 1190 . The close relative of the Lancaster family, Thomas son of Gospatrick, the direct male descendant of Ketel son of Eldred, founded a priory at Preston Patrick by 1199. This was at first dependent on Cockersand, but Thomas moved it in 1201 and it became Shap Abbey. Between 1189 and 1194, William Marshal founded a priory of Augustinian canons at Cartmel. ${ }^{101}$ Hospitals and houses of regular canons were becoming common features of religious life in the region and, in spite of the perhaps uneasy initial relationship of the locality with Furness Abbey, both immigrants and natives shared in the introduction of modern religious institutions. This, too, must have helped the process of assimilation.

It was indeed the success of assimilation that is striking. By the early thirteenth century, without serious disruption, the Kirkby, Pennington and Copeland families, and others like them in the region, had adapted successfully to the changes that had followed the introduction of a foreign elite after the Norman Conquest. The families managed to fit smoothly into what had become a relatively seamless aristocratic network, the more easily perhaps because of the sustained significance in the area of the Lancaster family, at the very least closely linked to the native element. Anglo-Scandinavian landholding families, while certainly having to submit to and accommodate the dominant immigrants, never lost their place within the aristocratic network in the way that happened to a large extent in southern and Midland England. Neither did they form a surviving, but disadvantaged and separate elite as happened with native aristocracies in parts of Ireland and Wales. The sustained native role in the aristocratic network of the North-West likely enhanced the role in assimilation of intermarriage, which was common in the region and important certainly for the Kirkbys and the Copelands. It also enhanced more generally the role of the native landholding families themselves in the process of assimilation. While assimilation also succeeded ultimately in the south and Midlands, the relatively few native landholding patrilineages there played, as Thomas suggests, a rather limited role in it. ${ }^{102}$

\footnotetext{
${ }^{99}$ Ibid., I (1), 126-27. A leper hospital at Kendal was made dependent on Conishead Priory by 1184: Farrer, Early Lancashire Charters, pp. 356-60; D. Knowles and R.N. Hadcock, Medieval Religious Houses, 2nd edn (1971), pp. 155, 390; Register of St Bees, p. 119.

${ }_{100}$ Medieval Religious Houses, p. 330.

${ }^{101}$ Ibid., pp. 153-54, 185, 187, 191; Farrer, Early Lancashire Charters, pp. 341-45.

102 Thomas, English and Normans, pp. 137, 391-92.
} 
The families studied here participated in aristocratic retinues and in the acts of lords, both immigrant and native; they adopted new personal names that showed the influence of the immigrant lords but also a desire to follow new Continent-wide naming fashions. Neither of these trends can be said to have been forced on them. Also, where necessary or desirable, they, like other families around them, adopted the new forms of tenure that had arrived with the immigrants, while sometimes retaining the older kinds of tenure. The effects of the complexity that arose from this were mitigated by the practice of commutation for cash of important elements of different tenures, old and new, though this would not stop lawyers later having much to argue about. The tenurial situation was also complex in terms of the geographical spread of the families' lands and the number of their different lords, belying the picture of northern tenurial simplicity that is sometimes contrasted with the situation further south.

The areas where the Kirkbys, Penningtons and Copelands held lands, like much of the North, were coming to resemble the lands of castles, markets and boroughs from which the immigrants had come, though in the case of markets and boroughs somewhat belatedly and meagrely. Also, alongside the Continental immigrants themselves, these and other native families had to adapt, particularly in the second half of the twelfth century, to the spread of the new forms of royal and ecclesiastical administration, a shared experience that might have helped bind native and immigrant together. Native families themselves, together with immigrants, played an important role in the transformation of the local secular Church. If the foundation of Furness Abbey in 1127 had represented at first a clear foreign imposition, by the 1180 s the abbey was less clearly foreign and the elites of native origin were participating fully in the spread of other reformed conventual institutions in the region.

By the means described above, the native distinctiveness of families such as the Kirkbys, Penningtons and Copelands was progressively reduced and they could take their place among the knightly families of the region. And while of course the arrival of a foreign elite had influenced native families to adapt, the processes of adaptation cannot simply be seen as having been imposed by the immigrants; rather, the reaction of native elements in the aristocratic network should be seen as much more of a positive self-adaptation to an altered environment. 